\title{
EUPHEMISM IN DAVID CAMERON'S POLITICAL SPEECH IN ISIS ATTACKS
}

\author{
*NuzuliandaFebrinaPurba \\ **Dra. Meisuri, M.A. \\ **SyamsulBahri, S.S, M.Hum
}

\begin{abstract}
This study deals with euphemism in political speech of David Cameron about ISIS attacks. The objectives of the study were to find out the types of euphemsim used in DavidCameron's speech on ISIS attacks and the reason why the most dominant types was choosen. The study was conducted by applying descriptive qualitative method.The data for this study were David Cameron political speech transcript in 20 July 2015, 14 November 2015, 2 December 2015, 5 february 2016. The source of the data was from United Kingdom govermentwebsite .The data were analyzedusing the theory of Allan and Burridge (1991). The findings of the study showed that the types of euphemism used in David Camerons political speech about ISIS attacks were: figurative expression $(28,8 \%)$, circomlocution $(15,5 \%)$, ommision $(13,3 \%)$, ommision $(13,3 \%)$, hyperbole $(11,1 \%)$, understatement $(8,8 \%)$,flippancy $(8,8 \%)$, abbreviation $(8,8 \%)$, borrowing $(2,2 \%)$ and clipping $(2,2 \%)$. Figurative expression as the most dominant type used by David Cameron because it make words in speech more organized as a nice thing to be spoken in public in order to convince people.
\end{abstract}

Keywords: euphemism, euphemism types, speech, politic 


\section{INTRODUCTION}

People need language to communicate in daily life, despite the fact that not all of them can fluently communicate each other if they cannot get the true meaning of their interlocutors. Nowadays, speakers prefer to use metaphors to make their words more interesting.For example, when someone says "he got a green light", and the listener feels confused cause there is no traffic light there. However, the speaker has another intention behind his words, yet the listener cannotinstantly catch the true meaning . In order to synchronize the real meaning of a communication between speaker and listener, semantics plays animportant role.

In linguistics, semantics is known as a study of meaning through language. The influence of semantics can be seen on political sphere, mass media, and more simply in daily conversations. One of the kind of semantics that mostly appear and used in daily language is euphemism.

Euphemism technique consists of replacing words referring to something offensive or indelicate in order to make it sound more pleasant to be acceptable ones (Leech, 1981:45). For example, peopleare recommended not to say the word 'epilepsy' directly in formal forums, it is more polite to say 'falling sickness'. The use of euphemism in that example is aimed to replace something distasteful to be said to morepolite words. People mostly replace indelicate words with the better ones by using euphemism to create a harmonious communication. 
Generally, politics is one of the fields in which the use of euphemism is highly noticed due to politician intention to lead better the society by camouflaging the grim reality things by using euphemism technique.

Allan and Burridge (2006:96),stated that euphemistic use in political language responds to the politicians' need that their self-image be appreciated by approved in the community to the desire of maintaining their positive face.The more people believe them, the more the politicians can take the advantages from it, such as increasing of their reputation, and it will of courseaffecting their electability in the election.

In 2015, Cameronhim as the Prime Minister of UK at that time delivered a speech devoted to the radical group ISIS in terms of created more conducive atmosphere for the people who felt threatened by the actions of ISIS. Burridge (2004:4) said, by referring to topics likea war or killing euphemistically, those topics mightappear tolerable. Euphemisms create an excuse for such social actions and lead humans to better perceive them with a respect.

\section{REVIEW OF LITERATURE}

\section{Semantics}

Saeed (2003:3), defines semantic as the study of meaning communicated through language. However,Leech (1981:XI) suggest that, semantics as the study of meaning was central to the study of communication that becomes more and more 
crucial factor in social organization, therefore the need to understand it becomes more and more pressing.

Semantics tries to understand the meaning aslanguage elements and how it is constructed by language as well as interpreted, obscured and negotiated by speakers and listeners of that language. Semantics has greatly developed and became worthy to study. There are two factors that make semantics become important and worthy study. First, meaning is strictly connected with communication. A certain meaning delivered through communication plays an important role in human life. Second, the process of human attempts to comprehend the nature of meaning involves the mental ability by the use of reasoning and perception.

In order to understand the class and purpose of any meaning in the semantic, Leech (1981:9) classifies the semantic meaning into two types; conceptual and associative which contains 5 types; connotative, social, affective, reflective, collocative, thematic meaning.

Basically, euphemism is a part of semantic and as a way of conveying the intents of talk by sublimating the meaning. Euphemism seem as an associative meaning engineer cause associative meaning is unstable meaning and has variants of individual experience and euphemism can represent all of associative meaning types (Leech, 1981:21\&45). 


\section{Euphemism}

Allan \&Burridge (1991:5) state that, euphemisms are alternatives to dispreferredexpression are used in order to avoid possible loss of face. The statement above, people use the euphemism term is as an alternative expression to avoid mentioning the taboo or unpleasant word to keep the relationship between speaker and listener.

According to Allan and Burridge (1991:14-19), euphemism is formed through several ways, such as:

a. Figurative

- Figurative words formed in symbolic or figuratively. Using figurative words can make words more vivid and interesting than the straight talk. Figurative formed in 5 types: . Simile : a comparison using "like" or "as" e.g: as light as a feather (too easy)

- Personification: making an inanimate object or animal act like a person.

e.g: The car painted limee green, raced by screaming for attention (an attention seeker).

- Metaphor : a comparison of two unlike things that suggests similarity in two of them

e.g: It is going to be clear skies from now on (life is going to be without hardships) 
- Idiom : an expression that cannot be understood from the individual meanings of its elements

e.g. Once in a blue moon (things that rarely happen)

- Irony: the opposite of what it meant

e.g: The doctor is as kindhearted as a wolf

b. Flippancy ; the initial form of the word different with the result after the word

had soften,

e.g: longmarchmeans demonstration

c.Remodeling; remodel of old statement with the new ones based on the situation, e.g: hopelesshagen » Copenhagen+hopeless; represent Copenhagen people condition.

d.Circumlocution ; small words subtituted with long words,

e.g: warehouse isleftluggage office

e. Clipping ; long words to subtitutes the small word

e.g: honorarium meanssalary

f. Acronym; shortening several words into one words

e.g: UNICEF » UnitedNations International Children's Emergency Fund

g. Abbreviation; abbreviating words into letters to make it looks sophisticated, e.g: FYI » For Your Information 
h.Ommision, ommision divide into two types:

○ Metonymy; a words that stand in for another words for legal terms e.g: The suits » bussinesman

- Synecdoche; changing of general words become to special words e.g: got cough » running nose

i. Hyperbole; exxageration with extra drama or comedy depends on the situation e.g: he is skinny as a toothpick

j.Understatement; changing words into milder words in order to make the situtation seems not too bad e.g: sleep » die

k. Borrowing; term from another language

e.g: 'very' borrowed from old Frenchlanguage 'verai' means true

1. Indirection; firstwors can explain the whole words

e.g: 'how did they get usinto this mess' underlined words explain that they're in the trouble.

m. Abstraction; cover up words from the widest

e.g: judge me by my record ,underlined word means the performance of his work. 


\section{RESEARCH METHODOLOGY AND FINDINGS}

\section{Methodology design}

This research was conducted by using descriptive qualitative design.In conducting this qualitative research, there were some types of qualitative research which are briefly just eight of the most widely used approaches: ethnography, focused interviews, case study, document analysis, naturalistic observation, phenomenology studies and historical studies (Ary,et.al 2002:25). Thus, this research used focused to document analysis.

\section{The source of data}

The data for this research were the transcript of David Cameron speech about ISIS attacks. The source of the data for this research were from United Kingdom government website. The researcher took the 45 utterances that contained euphemism in David Cameron speech about ISIS attacks in July,November and December 2015 from Prime Minister's office andNinestiles School Birmingham and the last in February 2016 from Downing Street.

\section{The ananysis of data}

The transcript data of David Cameron political speech about ISIS attacks were identified through 13 types of euphemism then classified which euphemism were used in the political speech. After that, the types of euphemism that had found calculated use the number and percentage of each type using mathematic formula. Furthermore, specify the most dominant types then describe the reason of dominant type mostly used. 
Table. 4.1

Euphemism used in David Cameron Political Speech on ISIS Attacks

\begin{tabular}{|c|c|c|c|c|c|c|c|}
\hline \multirow[t]{2}{*}{ No } & \multirow[t]{2}{*}{ Types } & \multicolumn{4}{|c|}{ Speech } & \multirow[t]{2}{*}{ Frequency } & \multirow[t]{2}{*}{ Percentage } \\
\hline & & I & II & III & IV & & \\
\hline 1 & $\begin{array}{l}\text { Figurative } \\
\text { expression }\end{array}$ & 2 & 1 & 6 & 4 & 13 & $28,8 \%$ \\
\hline 2 & Flippancy & 1 & 1 & 2 & - & 4 & $8,8 \%$ \\
\hline 3 & Circomlocution & 1 & - & 4 & 2 & 7 & $15,5 \%$ \\
\hline 4 & Clipping & 1 & - & - & - & 1 & $2,2 \%$ \\
\hline 5 & Ommision & - & 1 & 4 & 1 & 6 & $13,3 \%$ \\
\hline 6 & Hyperbole & 2 & - & 2 & 1 & 5 & $11,1 \%$ \\
\hline 7 & Understatement & 1 & & 1 & 2 & 4 & $8,8 \%$ \\
\hline 8 & Borrowing & - & - & - & 1 & 1 & $2,2 \%$ \\
\hline 9 & Abbreviation & - & 2 & - & 2 & 4 & $8,8 \%$ \\
\hline 10 & Remodelling & - & - & - & - & - & - \\
\hline 11 & Indirection & - & - & - & - & - & - \\
\hline 12 & Acronym & & & & & & \\
\hline 13 & Abstraction & & & & & & \\
\hline & Total & 8 & 3 & 19 & 13 & 45 & $100 \%$ \\
\hline
\end{tabular}




\section{Findings}

After analyzing the data, the findings of this research were presented as follows:

1. There are nine types of euphemism applied in political speech of ISIS attacks by David Cameron from 13 types of euphemism in Allan and Burridge theory. They were figurative expression with thirteen items $(28,8 \%)$,flippancy with four items $(8,8 \%)$, circomlocution with seven items $(15,5 \%)$, clipping with one item $(2,2 \%)$, ommision with six items $(13,3 \%)$, hyperbole with five items $(11,1 \%)$, understatement with four items $(8,8 \%)$, borrowing with one item $(2,2 \%)$ and abbreviation with four items $(8,8 \%)$. Remodelling, acronym, indirection and abstraction were the types of euphemism that not found in David Cameron speech about ISIS attacks.

2. The most dominant types used in political speech of ISIS attacks by David Cameron was figurative expression $(26,8 \%)$ thus the reason this type mostly used based on the theory of Burkholder and Henry (2009:100) proved that figurative mostly use in political speech to make words in speech more organized as a nice thing to be spoken in public in order to convincing people. 


\section{Data Findings}

\begin{tabular}{|c|c|c|}
\hline - Figuration & - Flippancy & - Circomlocution \\
\hline Clipping & Ommision & - Hyperbole \\
\hline Understa & Borrowing & Abbreviation \\
\hline
\end{tabular}

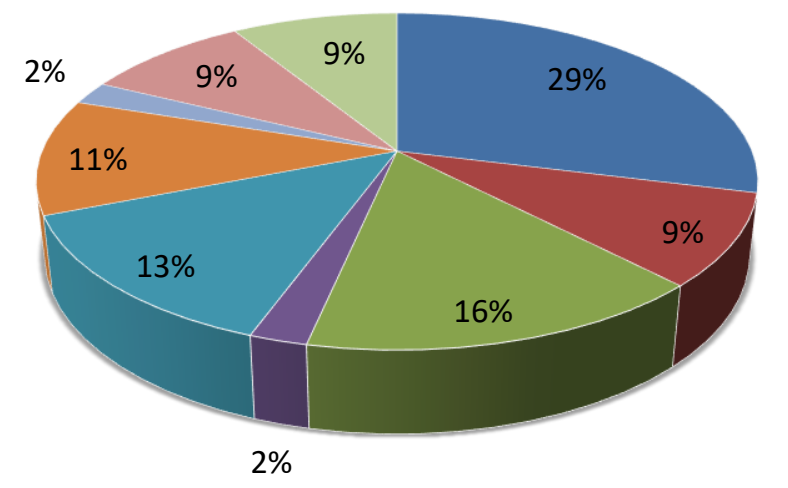




\section{DISCUSSION}

Some important points showed the differences and the similar from the previous studies that also focussed on the similar subject matter with the researcher. One of the previous study by Abidi (2015) who conducted study of euphemism in Tony Blair's political discourse, found that in Tony Blair's discourse have 18 statements which contain 8 euphemism which understatement was the most dominant type of euphemism Tony Blair used with 7 number on that discourse.

On the other hand, Fernandez (2014) studied euphemism used in political discourse of British press. In his study, Fernandez found 123 items that using euphemism in British press. Among 123 items encountered, there were 10 types of euphemism from 13 types of euphemism were used in British press and the most dominant type used was understatement in 32 quotes.

In another case, Nguyen (2012) who have done study of some linguistic features of Barack Obama's English speeches. Nguyen found that figurative were the most type Obama used in 50 speeches of Obama. The type of figurative mostly appear in Obama speeches were metaphor. There were 15 metaphor found in Nguyen study. .Moreover Nguyen have found the distinctive features of metaphors in signaling affection and they help us identify the aesthetic in speeches and understand the speaker's emotion. 
In the other hand, there were three researchers that were analyzed euphemism using B.Warren theory. Warren theory based on the semantic innovation, which formed in implication, particularization, metaphor, understatement, reversal, overstatement. Sari (2013) in his study of Euphemism in language of politic express newspaper, and Prasetyo\&Widyastuti (2014) in their study of Application of B.Warren's model to political euphemism in United States presidential debate 2012. The results of their study were semantic shifts were the most types (31 items) used in Sari (2013) study, and metaphor were the most types used in Prasetyo\&Widyastuti (2014), there were 17 items used in that study.

While in this study of euphemism in David Cameron political speech on the ISIS attacks, found 9 types of euphemism works in Cameron speech. The researcher focused to using Allan \&Burridge theory to analyzing the study. But the most dominant types of euphemism which is figurative expression which the most figurative types appear in speech was metaphor (6 items), almost similar with Nguyen study. Figurative in political speech may worthy for maintaining speaker's manner. 


\section{CONCLUSION AND SUGGESTION}

\section{Conclusion}

There were some main points that can be considered as the conclusions of the study, they are:

1. There were 9 types of euphemism from 13 types of euphemism used by David Cameron in his speech about ISIS attacks. There were figurative expression (28,8\%), circomlocution(15,5\%), ommision(13,3\%), hyperbole (11,1\%), understatement (8,8\%), flippancy $(8,8 \%)$ abbreviation $(8,8 \%)$, clipping $(2,2 \%)$ and borrowing $(2,2 \%)$

2. The type of euphemism which highly used was figurative expression was used by David Cameron in his political speech about ISIS attacks to provedthat by theories of of Burkholder and Henry (2009:100) that figurative mostly use in political speech to make words in speech more organized as a nice thing to be spoken in public in order to convince people.

\section{Suggestions}

There are several suggestions that can be offered based on the analysis of the study, they are:

1. Theoretically; as the references in learning a language in semantic knowledge especially in euphemism will give us the contribution to find real meaning in society, and the readers who are interested in conducting related study . 
2. Practically; the researcher hopes that this research will be useful for the enrichment of studying semantic and euphemism, especially in English Department, Faculty of Languages and Arts, State University of Medan. 


\section{REFERENCES}

\section{Books and Journals}

Abidi, Mohamed. (2015) Euphemism in Tony Blair's Political Discourse in the Iraqi war2003.International Journal of Humanities and Cultural Studies, Vol 2, No.1.University of Tunisia

Allan, Keith and Burridge, K. 1991. Language Used as a Shield and Weapon. Oxford: Oxford University Press

Allan, Keith and Kate Burridge (2006) Forbidden Words. Taboo and the Censoring of Language.Cambridge: Cambridge University Press.

Ary, Donald. 2002. Introduction to Research in Education. Stamford:Wadsworth

Burkholder, T. R. \& Henry, D. (2009).Criticism of Metaphor. In J.A. Kuypers (Ed.), Rhetorical Criticism: Perspectives in Action (pp. 97-114). Lanham, MD: Lexington Books

Burridge, Kate. 2004. Blooming English. New York: Cambridge University Press.

Fernandez, ElicierCrespo. (2014) Euphemism and Political Discourse in the British Regional Press. Journal forBrono Studies for English,Vol 40,No.1

Leech, Geoffrey. 1981. Semantics. The study of meaning. Second edition. Harmondsworth :Pelican books. 
Prasetyo, Andik\&Widyastuti.(2014) Application of B. Warren's Model to

Political Euphemism in United States Presidential Debate 2012.Language Horizon,

Vol 4, No 1. Surabaya State University

Saeed, John L. 2003.Semantics. Second edition.Oxford :Blackwell

Sari, Dina Mayang. (2013) Euphemism in Language of Politic in Padang Express Newspaper.E-Journal English Language and Literature,Vol 1, No.2 State University of Padang 